\title{
A new vision of the origin and the oocyte development in the ostariophysi applied to Gymnotus sylvius (Teleostei, Gymnotiformes)
}

\author{
Gisleine Fernanda França ${ }^{1,2}$, Harry J. Grier ${ }^{3}$ and Irani Quagio-Grassiotto ${ }^{2}$
}

Based on new knowledge coming from marine perciform species, the origin of oocytes and their development in the Ostariophysi, Gymnotus sylvius is described. In both Gymnotus sylvius and marine perciform fish, oogonia are found in the germinal epithelium that forms the surface of the ovarian lamellae. At the commencement of folliculogenesis, proliferation of oogonia and their entrance into meiosis gives rise to germ cell nests that extend into the stroma from the germinal epithelium. Both cell nests and the germinal epithelium are supported by the same basement membrane that separates them from the stroma. At the time of meiotic arrest, oocytes in a cell nest become separated one from the other as processes of prefollicle cells, these being derived from epithelial cells in the germinal epithelium, gradually encompass and individualize them while also synthesizing a basement membrane around themselves during folliculogenesis. The oocyte enters primary growth while still within the cell nest. At the completion of folliculogenesis, the oocyte and follicle cells, composing the follicle, are encompassed by a basement membrane. The follicle remains connected to the germinal epithelium as the both share a portion of common basement membrane. Cells originating from the stroma encompass the ovarian follicle, except where there is a shared basement membrane, to form the theca. The follicle, basement membrane and theca form the follicular complex. Oocyte development occurs inside the follicular complex. Development is divided into the stages primary and secondary growth, oocyte maturation and ovulation. Cortical alveoli appear in the ooplasm just prior to the beginning of secondary growth, the vitellogenic stage that begins with yolk deposition and proceeds until the oocyte is full-grown and the ooplasm is filled with yolk globules. Maturation is characterized by the germinal vesicle or nuclear migration, germinal vesicle breakdown or nuclear envelop fragmentation and the resumption of meiosis. At the ovulation the egg is released from the follicular complex into the ovarian lumen. When compared to marine Perciformes that lay pelagic eggs, oocyte development in Gymnotus sylvius has fewer steps within the stages of development, the two most remarkable being the absence of oil droplet formation during primary and secondary growth, (and the consequent absence of the oil droplets fusion during maturation), and the hydrolysis of yolf preceding ovulation.

Tendo por base os novos conhecimentos oriundos de recentes estudos com Perciformes marinho, a origem e o desenvolvimento dos oócitos no Ostariophysi Gymnotus sylvius são aqui descritos. Da mesma maneira que ocorre nos Perciformes, em Gymnotus sylvius as oogônias são encontradas no epitélio germinativo que margeia as lamelas ovígeras. No início da foliculogênese, a proliferação das oogônias e sua entrada em meiose dão origem a ninhos de células germinativas que se projetam em direção ao estroma ovariano, a partir do epitélio germinativo. Os ninhos e o epitélio germinativo são suportados pela mesma membrana basal que os separa do estroma. Coincidindo com a paralisação da meiose os oócitos, presentes nos ninhos, são separados uns dos outros por processos citoplasmáticos das células pré-foliculares. As células pré-foliculares derivam do epitélio germinativo sendo, portanto, inicialmente células epiteliais. Durante a foliculogênese, ao mesmo tempo em que envolvem os oócitos individualizando-os, as células pré-foliculares sintetizam a membrana basal ao seu redor. Os oócitos entram em crescimento primário ainda dentro dos ninhos. Ao término da foliculogênese, o oócito e as células foliculares que compõem o folículo são circundados pela membrana basal. $\mathrm{O}$ folículo permanece conectado ao epitélio germinativo uma vez que ambos compartilham uma porção comum da membrana basal. Células oriundas do estroma circundam o folículo ovariano exceto na região de compartilhamento da membrana basal formando a teca. $\mathrm{O}$ folículo, a membrana basal e a teca formam o complexo folicular. $\mathrm{O}$ desenvolvimento do oócito ocorre dentro do complexo folicular e compreende os estágios de crescimento primário e secundário, maturação e ovulação. Os alvéolos corticais surgem no ooplasma momentos antes do início do crescimento secundário ou estágio vitelogênico que tem início com a deposição de vitelo, progride até o oócito esteja completamente desenvolvido e o ooplasma preenchido pelos glóbulos de vitelo. A maturação é caracterizada pela migração do núcleo ou vesícula germinativa,

${ }^{1}$ Programa de Pós-Graduação em Biologia Celular e Estrutural, Instituto de Biologia - UNICAMP, Campinas, SP, Brazil. ${ }^{2}$ Departamento de Morfologia, Instituto de Biocências, IBB-UNESP. Distrito de Rubião Jr, s/n, 18618-000 Botucatu, SP, Brazil. iraniqg@ibb.unesp.br

${ }^{3}$ Florida Fish and Wildlife Research Institute, St. Petersburg, FL, United States. 
pela quebra da vesícula germinativa, ou seja, pela fragmentação do envoltório nuclear e, retomada da meiose. Na ovulação o ovo é liberado do complexo folicular para o lúmen ovariano. Em comparação com os Perciformes marinhos com ovos pelágicos, o desenvolvimento oocitário em Gymnotus sylvius tem menos etapas dentro dos estágios de desenvolvimento, sendo as duas mais notáveis delas as ausências da formação das gotas de lipídio durante os crescimentos primário e secundário (e a consequente fusão das gotas para formar um único glóbulo de lipídio durante a maturação) e, a hidrólise do vitelo antecedendo a ovulação.

Key words: Folliculogenesis, Primary growth, Secondary growth, Maturation, Ovulation.

\section{Introduction}

Oocyte growth and maturation are well known processes in fish oocytes and are used to determine the phase of ovarian development during the spawning cycle. Oocyte growth can be divided into a previtellogenic stage or primary growth, and into a secondary growth stage known as vitellogenesis (Patiño \& Sullivan, 2002; Grier et al., 2009). During the previtellogenic period, a large amount of RNA accumulates in the cytoplasm of the oocyte, membranous organelles proliferate, and in many species, primarily those that scatter eggs in saltwater, oil droplets appear around the nucleus. At the end of the previtellogenic stage, cortical alveoli are formed within the oocytes of many species, excepting killifish where cortical alveoli are the first significant structures to form in the ooplasm (Selman \& Wallace, 1989). The deposition of yolk globules and the thickening of the zona pellucida, that begins to form during the latter part of primary growth, characterize vitellogenesis or secondary growth stage (Wallace \& Selman, 1981, 1990; Selman \& Wallace, 1989). During secondary growth, vitellogenin, synthesized by the hepatocytes and released into the blood, is incorporated by the oocyte via a receptor mediated process, and gives rise to yolk globules (see Patiño \& Sullivan, 2002; Le Menn et al., 2007; Grier et al., 2009 for reviews). During the final part of oocyte development known as oocyte maturation, the germinal vesicle (the nucleus) migrates to the animal pole where the micropyle is located. During oocyte maturation in the major saltwater species of fish, the oil droplets that form during primary and secondary growth progressively fuse, becoming larger oil globules until only one large globule remains. In pelagophil species, the yolk globules also fuse preceding ovulation, resulting from a pronounced proteolysis of the vitellogenin-derived yolk proteins whose amino acids become osmotically active. Via osmosis the oocyte hydrates. In the benthophil species, yolk-protein proteolysis is limited and oocyte hydration is more modest (LaFleur et al., 2005). Oocyte development occurs inside the follicular complex (Grier et al., 2009) formed by the oocyte that is surrounded by the follicle cells, a basement membrane and the thecal cell layers (see Grier et al., 2009 for review).

Compared to oocyte development, the origin of the oocytes and the formation of the follicles in which they develop are not well studied. Folliculogenesis occurs in cell nests within the germinal epithelium that borders the ovary lumen. The nests are composed by proliferating oogonia and early prophase oocytes (see Grier et al., 2009 for review).
Despite the fact that the literature on oocyte development in fish is vast, there is no standard consensus regarding the nomenclature used to characterize the different aspects of oocyte development. The usage of non-standardized nomenclature has generated many difficulties in communication among the scholarly. Recently, a staging schema of oogenesis in fish has been developed that could be applied to the oocyte development in many species of fish (Grier et al., 2009) with appropriate modifications. The schema is based on the morphological and physiological events taking place during fish oogenesis and reflects the cellular alterations occurring in the oocyte between its differentiation from an oogonium to ovulation as an egg. However the staging schema by Grier et al. (2009) was primary developed from marine species of Perciformes and until now was not apply to the oocyte development in freshwater fish.

The fish fauna of freshwater in the Central and South America is predominantly composed by species of the superorder Ostariophysi (Reis et al., 2003). Among the Ostariophysi, the order Gymnotiformes is the least known regarding its reproductive biology. Gymnotiformes, the electric fish, is a fascinating assemblage of freshwater fishes that share the unusual ability to produce and sense electric fields used for electrolocation and social communication. These fishes, like the catfishes, have nocturnal habits and are found throughout the humid neotropical region in most lowland aquatic environments from the South of Mexico to the North of Argentina (MagoLeccia, 1994; Alves-Gomes et al., 1995).

In an attempt to apply the staging schema of oogenesis in fish, developed by Grier et al. (2009) to the freshwater ostariophysians, herein, the origin of and development of oocytes in the Gymnotiformes, Gymnotus sylvius, were studied using high resolution light microscopy. Additional ultrastructural informational is also provided.

\section{Material and Methods}

Sexually mature females of Gymnotus sylvius were collected monthly in the Tietê River (22 $41^{\prime} 00.9^{\prime} \mathrm{S}$ 48 19'58.1'W), São Paulo State, Brazil, from September 2006 to April 2008. The fishes were identified and kept in the fish collection of Laboratório de Biologia e Genética de Peixes (LBP), Departamento de Morfologia, Instituto de Biociências de Botucatu/UNESP, with the collection number LBP2845.

The specimens were anaesthetized with $0.1 \%$ benzocaine and killed according to the institutional animal care protocols 
and approval. Their ovaries were quickly removed and fixed by immersion in $2 \%$ glutaraldehyde and $4 \%$ paraformaldehyde in Sorensen's phosphate buffer (0.1 M, pH 7.2) for at least $24 \mathrm{~h}$.

For light microscopy, ovaries were dehydrated in ethanol and embedded in historesin (Technovit 7100). Sections (3-5 $\mu \mathrm{m})$ were stained with toluidine blue $0.5 \%$ and periodic-acidSchiff (PAS)/haematoxylin/metanil yellow (Quintero-Hunter et al., 1991). Toluidine blue is a metacromatic basic dye used at different $\mathrm{pH}$ to detect acid polysaccharides mainly those that are highly sulphated. Acid polysaccharides are stained lilac. As a basic dye, toluidine blue also reacts with the nucleic acids that stain in distinctive hues from blue. The PAS method by itself (Pearse, 1985) or associated with other dyes (Quintero et al., 1991) is used to detect neutral polysaccharides. Neutral polysaccharides are stained in magenta.

Gonadal tissues were evaluated using a computerized image analyser (Leica Qwin 2.5).

For electron microscopy, ovaries were post-fixed for $2 \mathrm{~h}$ in the dark in $1 \%$ osmium tetroxide (in the same buffer). In order to highlight the cellular structures, block-staining was carried out using an aqueous solution of 5\% uranyl acetate for $2 \mathrm{~h}$. Subsequently, the specimens were dehydrated and embedded in Araldite, sectioned and post-stained with a saturated solution of uranyl acetate in $50 \%$ ethanol and $0.2 \%$ lead citrate in $\mathrm{NaOH}(1 \mathrm{~N})$. Electromicrographs were obtained using a Philips - CM 100 transmission electron microscope.

\section{Results}

\section{Folliculogenesis}

The cystovarian ovary of Gymnotus sylvius has numerous lamellae that project into the ovarian lumen; the lamellar surface is the germinal epithelium. The germinal epithelium is formed by squamous epithelial cells among which are single oogonia. The scattered oogonia characterize the discontinuity of the germ cell component in the epithelium. The single oogonium in the epithelium has an ovoid and slightly basophilic nucleus and a clear cytoplasm. In the epithelium, oogonia are surrounded by the flattened epithelial cells that have an elongated nucleus, rest upon the basement membrane and isolate the oogonia from the ovary lumen (Fig. 1A).

Proliferation of an oogonium gives rise to cell clusters, the germ cell nests, that protrude into the stroma but remain separated from it by the basement membrane. The generations of oogonia within cell nests are large and differ from those that are quiescent in the epithelium by having a spherical and voluminous nucleus with a distinctive nucleolus (Fig. 1B). These oogonia are gradually individualized by prefollicle cells that are derived from epithelial cells in the epithelium; they surround the oogonia, separating them one of another (Fig. 1B). In the nests, individualized oogonium proliferate by mitosis giving rise to cell clusters that remain together. The cell nests are in the epithelium and are limited by the basement membrane, PAS reactive (Fig. 1C). Oogonia in the same clusters simultaneously enter into meiosis, becoming prophase oocytes that are maintained in organized clusters (Figs. 1D, E). Leptotene and zygotene oocytes can be distinguished by their distinctive pattern of chromatin organization (Fig. 1D), and the bivalent chromosomes of pachytene oocytes are distinctly visualized (Fig. 1E). In a same cell nest, oogonia may co-occur along with clusters of prophase oocytes (Fig. 1E). The late pachytene oocytes are increasingly individualized by cells derived from the epithelium, the prefollicle cells, and at the time of meiotic arrest and the formation of the ovarian follicle, they become separated from nests (Figs. 1F, G). While still inside the nests, the oocyte can enter in primary growth as indicated by an enhancement of cytoplasmic basophilia (Fig. 1G). The ovarian follicles are forming during early diplotene when the oocyte is surrounded by the follicle cells that rest upon a thin basement membrane. Ovarian follicles that leave the nest, being separated from it by a basement membrane, remain attached to the lamellar epithelium by the basement membrane (Figs. 1A, C, D, E, F, H). Both the follicle and the germinal epithelium share a common length of basement membrane. In newly individualized oocytes the synthesis of RNAs is intense and can be first detected by a basophilic ring along the nuclear envelop and by the progressive enhancement of cytoplasmic basophilia (Figs. 1G, $\mathrm{H}$ ) or electron density (Figs. 2A, B, C).

\section{The primary growth stage}

During oocyte primary growth, the thecal layers become organized as the follicular complex is formed. Preceding and coincident with the formation of the thecal layers, the basement membrane continues to be synthesized. The basement membrane is a multilayered structure and is synthesized layer by layer by the follicle cells before the formation of the zona pellucida (Fig. 2A). The initial components of the basement membrane are first deposited upon the basal plasma membranes of the follicle cells, and then additional layers are progressively added to this firstformed basement membrane. A contribution of the epithelial cells to the building of the basement membrane in the shared regions could occur (Figs. 2E, H). The just-formed follicular complex is composed of the developing oocyte that is surrounded by a layer of follicle cells. These are encompassed by the basement membrane and by the thecal layers (Figs. 2A, B, D, E; 3A).

In the early primary growth or previtellogenic oocytes, nucleolar amplification results in production of multiple nucleoli that become oriented in a perinuclear position (perinuclear oocyte or perinucleolar step of primary growth). With the continuous synthesis of RNAs and their transport from the nucleus, the ooplasm becomes progressively more basophilic (Fig. 1D). As the previtellogenic oocytes develop, cellular organelles proliferate and mitochondrial clusters, initially localized in the proximity of the nucleus, scatter throughout the cytoplasm and become primarily localized at the oocyte periphery (Fig. 2C). The areas where the proliferating membranous organelles agglomerate correspond, using light microscopy, to the Balbiani bodies, and their dispersion (Figs. 2A, C, D, F, G) throughout the oocyte gives to the ooplasm a fissured, mottled appearance (Fig. 3A). During this period, oocytes increase in size and their cytoplasmic basophilia becomes intense (Fig. 3A). 

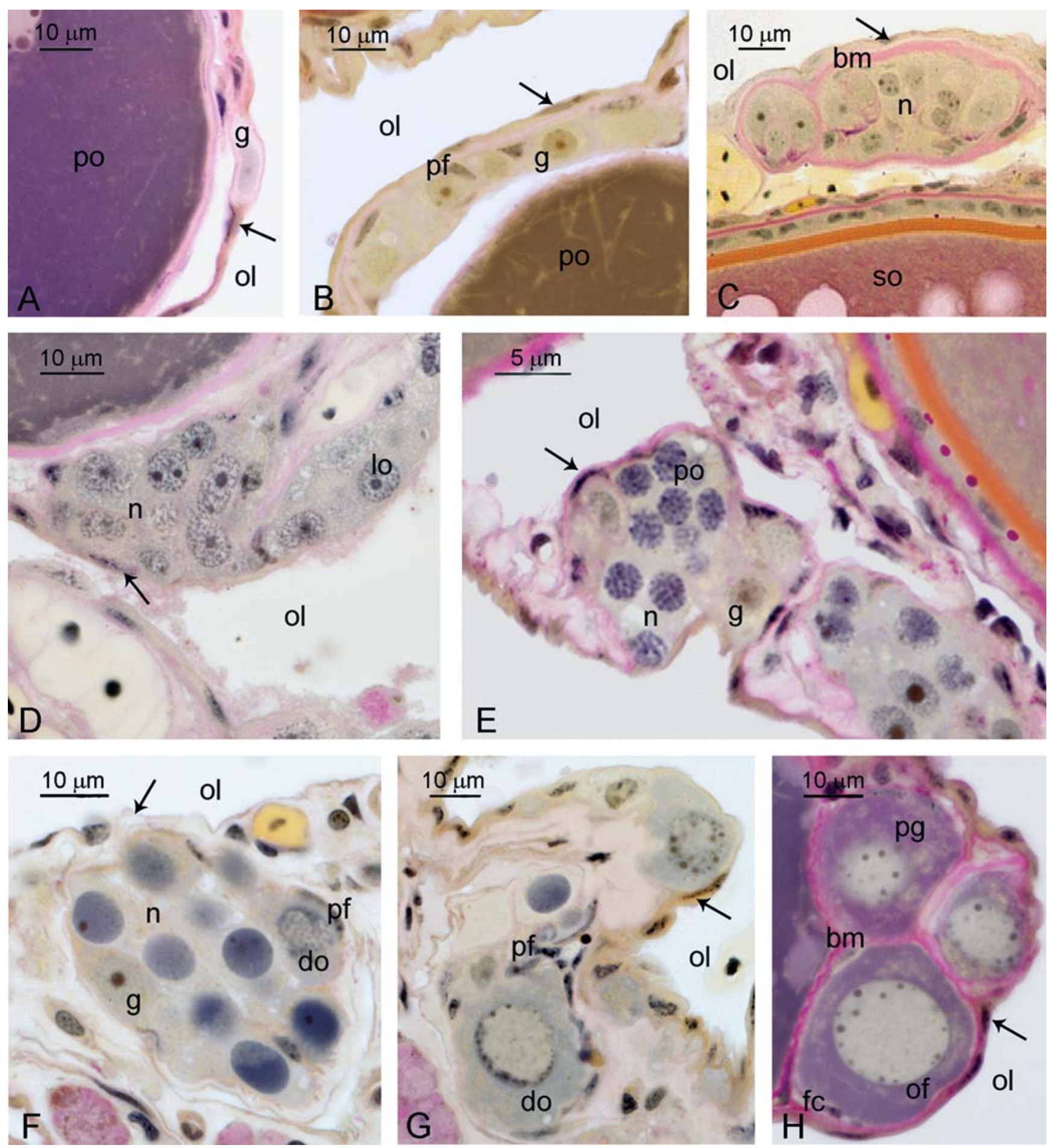

Fig. 1. Folliculogenesis in Gymnotus sylvius. Light Microscopy. A: Scattered in the germinal epithelium, the quiescent oogonium (g) is wrapped by the epithelial cells (arrow). Ovarian lumen: ol; Primary growth oocyte: po. B: Oogonia (g) proliferate and are surrounded by cells derived from the epithelium, the prefollicle cells (pf). Epithelium: arrow; Ovarian lumen: ol; Primary growth oocyte: po. C: Proliferation of the oogonium give rise to cell clusters, the germ cell nests (n), upon the magenta, PAS-positive basement membrane (bm) which in cross section is seen surrounding the nest. Epithelium: arrow; Ovarian lumen: ol; Secondary growth oocyte: so. D, E: In the nests (n), with the beginning and progress of meiosis, the prophase oocytes differentiate. In leptotene (lo) and in pachytene (po), they can be distinguished by the pattern of chromatin condensation. Proliferating oogonia (g) and prophase oocytes co-occur in a same nest (n). Epithelium: arrow; Ovarian lumen: ol. F, G: Prefollicle cells increasingly surround the oocytes, separating them one from another. As basement membranes form around individual oocytes and the prefollicle cells surrounding them, they are separated from the cell cluster. Completely surrounded by and individualized by 
prefollicle cells, early diplotene oocytes (do) enter into primary growth and are separated from the nest (n) at the completion of folliculogenesis. Epithelium: arrow; Ovarian lumen: ol; Oogonia: g. H: The ovarian follicles (of) are formed when the synthesis of the basement membrane (bm) around the follicle cells ( $\mathrm{fc}$ ) is complete. Multiple nucleoli, resulting from nucleolar amplification, are observed at the nuclear periphery (perinuclear step of primary growth). Within follicles, the primary growth oocytes increase in size (pg). Epithelium: arrow; Ovarian lumen: ol. Staining: periodic-acid-Schiff(PAS)/haematoxylin/metanil yellow.

As the basement membrane is being formed at the beginning of primary growth, microvilli appear along the oolema and along the plasma membrane of the follicle cells that face the oocyte (Figs. 4A, B, C, D). Around the microvillus, electron dense material is progressively deposited giving rise to the zona pellucida (Figs. 4E, F). Using metanil-yellow staining, the zona pellucida is seen as a yellow layer surrounding the oocyte which becomes thicker during oocyte growth. A yellow hue after metanil-yellow staining is a characteristic of protein structures (Figs. 3C, E, F). The micropyle, a discontinuity in the zona pellucida, is occupied by the micropylar cell (Fig. 3E-inset).

As the oocyte increases in size, there is an accompanied decrease in ooplasmic basophilia (Figs. 3A, B, C), and the oocyte enters into the cortical alveolar step of primary growth (Figs. $3 \mathrm{~A}, \mathrm{~B})$. Initially, this is marked by the appearance of clear and large vesicles scattered throughout the ooplasm. Using electron microscopy, the vesicles that compose the cortical alveoli can be detected very early during the primary growth stage, at the time of the zona pellucida begins its formation, and the thecal layers complete their organization (Figs. 4A, C, D, E). In the histological preparation stained by toluidine blue, the initial cortical alveolar vesicles are detected by their lilac hue (Fig. 3B-inset) and later their contents does not change. This is a characteristic of acid polisaccharides (Fig. 3D). The number of cortical alveolar vesicles increases during primary growth, and they become localized at the oocyte periphery in a multilayered structure composed of different sizes of alveoli (Figs. 3D, E, F). Viewed with electron microscopy the vesicles have a low electron density and fibrillar structure that reinforces their polysaccharidic nature (Figs. 5A, B). At this time, the nuclear outline becomes irregular (Fig. 3E). Close to the oolema, cortical alveoli continue to be formed and fuse to one another, and the zona pellucida becomes well developed (Figs. 3E; 5A).

\section{The secondary growth or vitellogenesis stage}

The start of the secondary growth is marked by the uptake of vitellogenin. Using electron microscopy, the beginning of the vitellogenic stage can be appreciates by the transport of highly electron dense particles in the intercellular space between the follicle cells and their accumulation at the external face of the zona pellucida and their appearance inside the oocyte close to the oolema. These particles fuse to one another and scatter throughout the ooplasm (Figs. 5C, E). Coinciding with start of vitellogenesis, the follicle cells become cuboidal (Fig. 5E). In the follicular complex, some thecal cells are observed in which the mitochondria are similar to those found in the steroidogenic cells (Fig. 5D). In histological preparations of the early vitellogenic/yolked oocytes, small yolk globules appear at the ooplasm periphery and progressively advance among the cortical alveoli. Due to their protein contents, the yolk globules stain a yellow hue with metanil-yellow (Figs. 6A, B). As vitellogenesis advances, the number of the yolk globules increases greatly, as does the size of the oocyte. The yolk globules fuse to one another, have an irregular outline and are poorly defined under light microscopy. They scatter throughout the cytoplasm in late vitellogenic/yolked oocytes. The zona pellucida becomes thicker. At this time, some acellular component deposited around the microvilli seems to be coming from an extra oocyte source (Fig. 5F).

The deposition of the yolk globules continues, and the ooplasm becomes filled with them; the oocyte becomes fullgrown when it reaches its maximum diameter of three micrometers (Fig. 6C). The oocyte is ready for maturation.

\section{Oocyte maturation}

The maturation stage is marked by nuclear migration into the animal pole (Fig. 6D). In the mature, preovulatory oocytes, there is no discernable alteration of the yolk globules (Fig. 6E) compared to those prior to the commencement of maturation (Fig. 6C). Despite their irregular outline, they remain individualized and do not fuse forming a liquid mass; there is no perceptive hydrolysis and/or hydration of the yolk (Fig. 6E-inset).

\section{Ovulation}

Ovulation is the stage in which the oocyte emerges from the follicle and becomes an egg. In recently ovulated eggs of Gymnotus sylvius, recovered from the oviduct, the yolk globules show some discreet fusion and, most of them keep the same characteristics observed in the full-grown and maturing oocytes. There is no a notable hydrolysis and hydration of the egg even after ovulation (Fig. 6F).

\section{Discussion}

Most of the reports on oocyte development in Teleostei mentioned the cell nests in the border of the ovigerous lamellae as the sites of origin of the oocytes and consequently of the ovarian follicles. Although correct, the oogonia, the true source of oocytes, are rarely seen in histological preparations that utilize paraffin-embedded tissues. In Gymnotus sylvius, as first demonstrated in the higher teleost, the common snook (Grier, 2000), and also in a salmonid, the rainbow trout (Grier et al., 2007), single oogonia are found scattered in the epithelium that borders the ovigerous lamellae, the germinal epithelium, and are completely wrapped by epithelial cells. In recent years, it was shown that the germinal epithelium that borders the ovigerous lamellae is the source of the germ cells 
Fig. 2 (next page). Early ovarian follicle development and the synthesis of the basement membrane in Gymnotus sylvius. Transmission Electron Microscopy. A: The just-formed ovarian follicle remains connected to the germinal epithelium (ge) by sharing a common, thin basement membrane (bm) with it. Primary growth oocyte nucleus (n) with a spherical nucleolus. Ovarian lumen: ol. B: The ovarian follicle is composed by the early primary growth oocyte (o) surrounded by the follicle cells (fc). The follicle is surrounded by and rests upon the basement membrane. Note the multi-layered basement membrane is shared by both ovarian follicle and the germinal epithelium. C: Inside the ooplasm the membranous organelles, mainly the mitochondria (m), proliferate forming aggregates that when visualized with light microscopy are the Balbiani bodies. Epithelium: arrow D: In the oocyte, multiple nucleoli (nu) are located at the nuclear periphery; the follicle cells synthesize new layers of the basement membrane which begins to become complex as multiple layers develop. Epithelium: arrow; Ovarian lumen: ol. E: The single layer of basement membrane that first appears just upon the follicle cell surface is discontinuous, and step by step additional layers are added to the one that forms first. Ovarian lumen: ol. F: Oocyte development: within the nucleus (n), the nucleoli become flattened against the germinal vesicle membrane, and many mitochondria (m) are observed in the ooplasm (o). Epithelium: arrow. G: The number of mitochondria $(\mathrm{m})$ increases considerably during primary oocyte growth. H: The synthesis of multiple, new layers to the basement membrane (bm) cause it to become thicker and complex. Ooplasm: asterisks; Follicle cells: fc; Germinal epithelium: ge. Ovarian lumen: ol. 


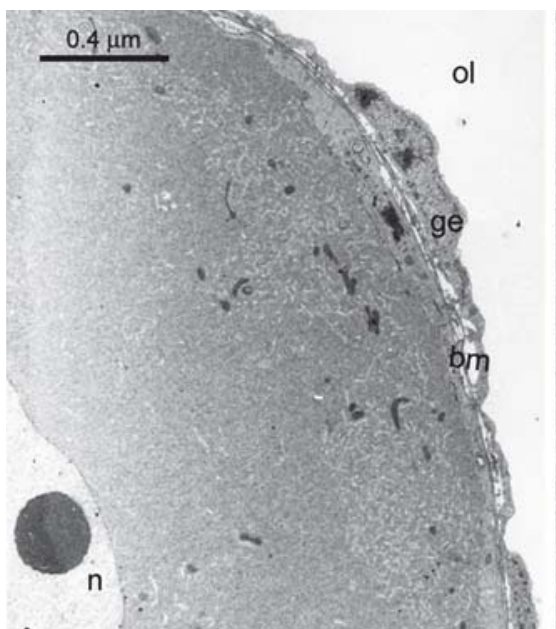

A
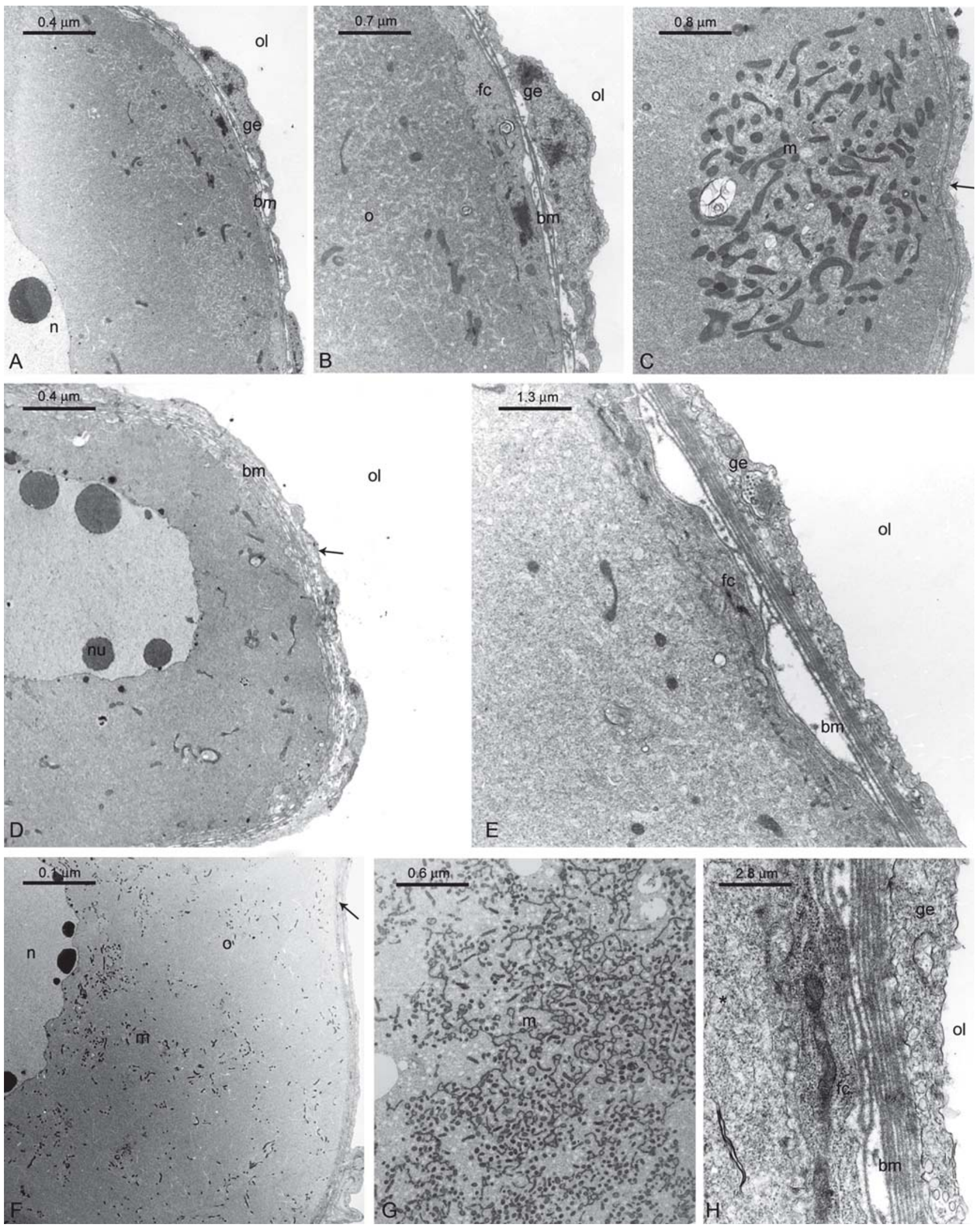
Fig. 3 (next page). Oocyte primary growth stage in Gymnotus sylvius. Light Microscopy. A: With the organization of the thecal layers (double arrow) the follicular complex is formed. Inside the follicular complex, primary oocyte growth (pg) continues, and the ooplasm becomes mottled (arrowhead). Cytoplasmic basophilia increases. Epithelium: arrow; Ovarian follicle: of; Ovarian lumen: ol. B, C: Clear vesicles (v) appear throughout the cytoplasm signing the entrance in the cortical alveolar step of primary growth. The vesicles are of variable sizes and become increasingly numerous. B-inset: The first vesicles appear (white arrow) in the ooplasm after the basement membrane (bm) is completely formed and before the zona pellucida becomes detectable. The vesicles have a lilac hue after Toluidine-blue staining. Epithelium: arrow; Ovarian lumen: ol. D, E: The large number of vesicles, stained lilac after toluidine blue, are localized at the ooplasm periphery where they form a multi-layered structure composed of cortical alveoli (ca). At this time the forming zona pellucida is detectable. E-Inset: In the oocyte outline, the micropyle (mi) can be seen as an interruption on the zona pellucida (zp). Epithelium: arrow; Ovarian lumen: ol. F: In a high magnification, small yolk globules are discernible in the ooplasm periphery signing the entrance of the oocyte in the secondary growth stage (early secondary growth or early yolked oocyte step). F-Inset: During oocyte development, the follicular complex remains connected to germinal epithelium by a sharing extension of the basement membrane. In this region the thecal layer is lacking, and the basement membrane of both the follicular complex and the epithelium are superposed. Epithelium: arrow; Ovarian lumen: ol. Staining: periodic-acid-Schiff(PAS)/haematoxylin/metanil yellow. 

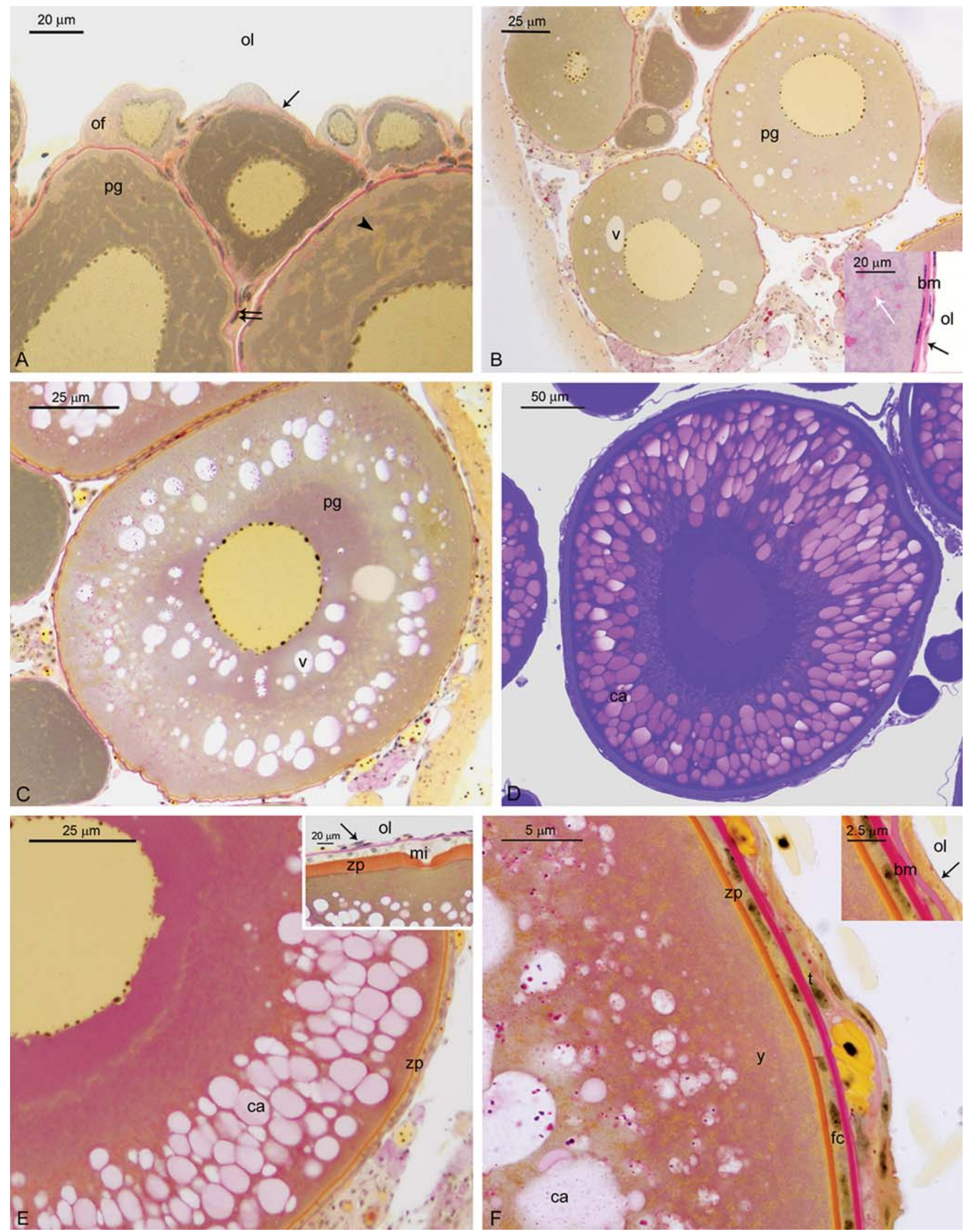
Fig. 4 (next page). Early follicular complex development and the appearance of the cortical alveoli in Gymnotus sylvius. Transmission Electron Microscopy. A: The vesicles (cav) of the forming cortical alveoli start to appear in the oocytes (o) at the same time as the first microvilli (arrow) are formed in the oolema. Ovarian lumen: ol. B: In these follicle complexes the follicle cells (fc) are squamous, the multilayered basement membrane (bm) is formed and $\mathbf{C}$ : the thecal layers are organized (t). Nucleus: $n$; Oocyte: 0 ; Germinal epithelium: ge; Ovarian lumen: ol. D: The amount of vesicles of the cortical alveoli (cav) increases, they have distinctive dimensions and some electron dense material appears inside them. Basement membrane: bm; Follicle cells: fc; Mitochondria: m; Theca: t. E: Electron dense material begins to be deposited around the microvilli giving rise to the zona pellucida (zp). Basement membrane: bm; Follicle cells: fc; Granulocyte: gr; Theca: t. F: The zona pellucida (zp) becomes thicker as its electron dense material (arrow) increases in thickness; the microvilli (mi) enlarge causing it to have a radiated appearance. In the plasma membrane of the follicle cells (fc), that faces the oocyte, some microvilli (arrowhead) are also formed. Inside the follicle cells there several elongate vesicles (v) are observed which containing is similar in density to those from the basement membrane (bm). Basement membrane: bm; Desmosomes: double arrow; Germinal epithelium: ge; Ovarian lumen: ol; Vesicles: v; Theca: t. 

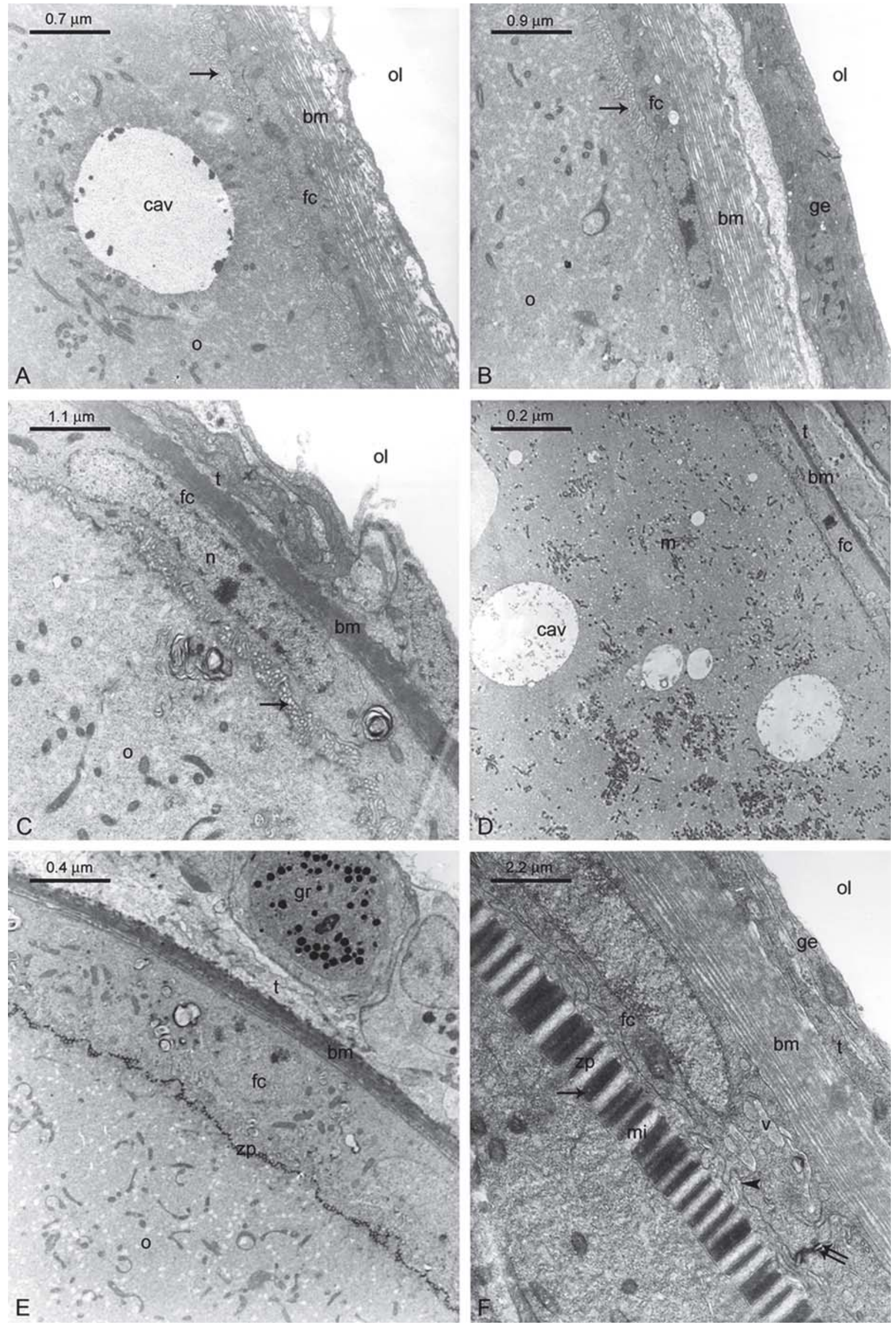
Fig. 5 (next page). Follicular complex development and the entrance into secondary growth in Gymnotus sylvius oocytes Transmission Electron Microscopy. A: The cortical alveoli are organized (ca). In the oocyte (o) periphery vesicles (cav) continue to be formed and fuse to one another. B: the large vesicles of the cortical alveoli (cav) are filled up by a fibrillar material (asterisks). Basement membrane: bm; Follicle cells: fc; Mitochondria: m; Theca: t. C: In the intercellular space between neighboring follicles cells (fc) high electron dense particles (arrow) are seen. Similar particles accumulate between the zona pellucida (zp) and the follicles cells. Basement membrane: bm; Follicle cells: fc; Mitochondria: m; Theca: t. D: In the theca externa (et) there are thecal cells (asterisks) in which the mitochondria (double arrow) are similar to those found in the steroidogenic cells. Basement membrane: bm; Follicle cells: fc; Internal theca: ic; Nucleus: n. E: The high electron dense particles are now seen inside the oocyte (o) at the ooplasma periphery. They fuse to one another (arrowhead) giving rise to the yolk globules (yg). The secondary growth is started. At this time the follicle cells (fc) become cuboidal. Basement membrane: bm; Theca: t; Nucleus: n. F: Also at this time, a large mass of a moderately electron dense material (arrow) appears to be incorporate to the zona pellucida (zp). Electron dense particles: arrowhead; Follicle cells: fc; O: oocyte. 

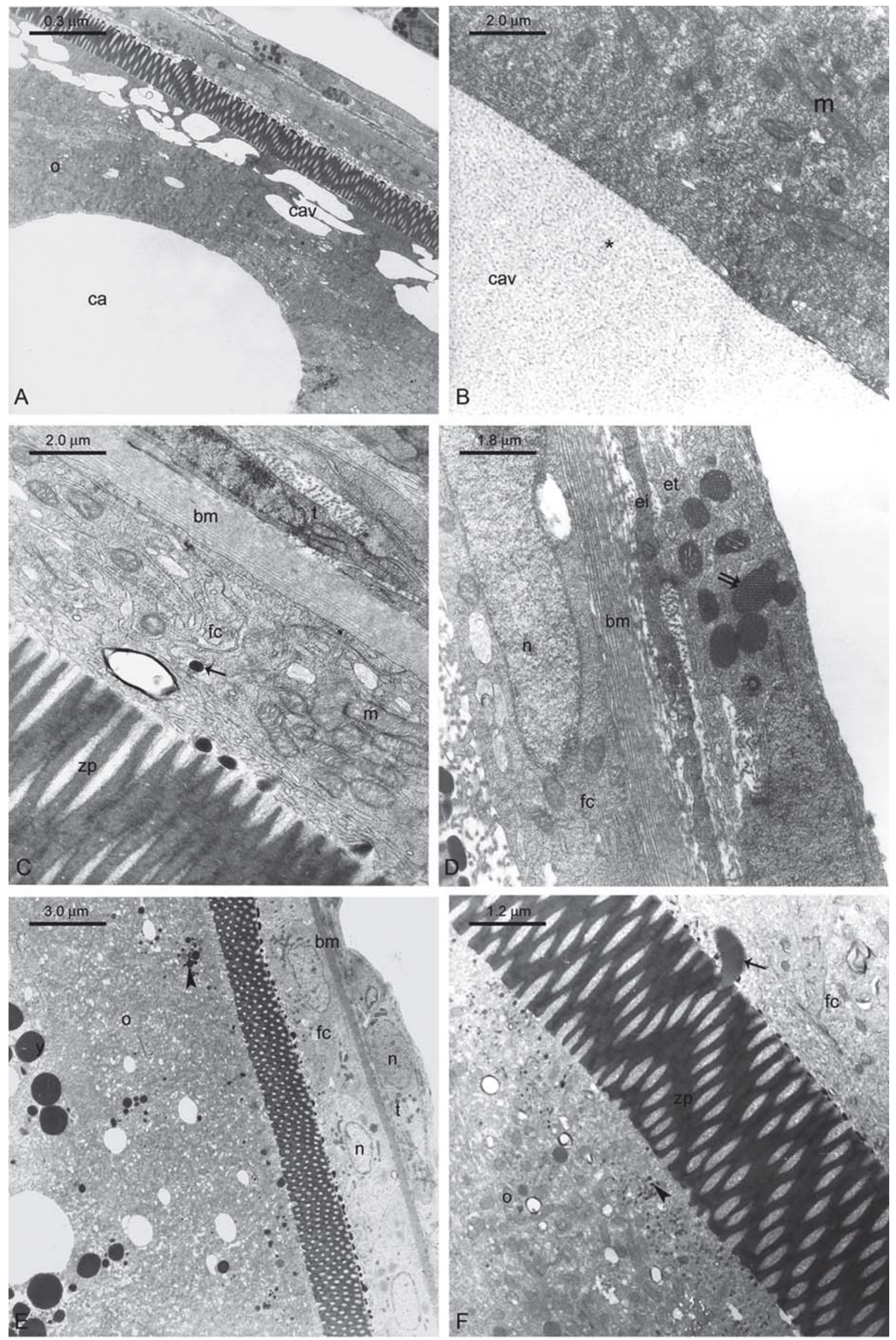
Fig. 6 (next page). Oocyte secondary growth stage, maturation and ovulation in Gymnotus sylvius. Light Microscopy. A-B: Yolk deposition: yolk globules appear and increase in number becoming scattered throughout the ooplasm (late secondary growth or late yolked oocytes step). Yolk globules are initially small and seem to fuse with one another and do not have an irregular outline. Zona pellucida: zp; Follicle cells: arrow; Ovarian lumen: ol. C: Oocyte continues increasing in volume during secondary growth; the cortical alveoli are displaced to the periphery as the yolk globules fill the ooplasm centrally (full-grown oocyte step). Ovarian lumen: ol. D: Maturation is started, and the germinal vesicle or nucleus (n) to the animal pole. Ovarian lumen: ol. E: Before germinal vesicle breakdown, the nucleus (n) is positioned at the cell periphery, near to the oolema. Einset: In a high magnification detail of the oocyte nucleus, the yolk globules remain discernible, are large and yolk hydration is not evidenced. Ovarian lumen: ol. F: Even after ovulation, there is only a discreet fusion of the yolk and hydrolysis and hydration are not discernible in the eggs. Staining: periodic-acid-Schiff(PAS)/haematoxylin/metanyl yellow. 

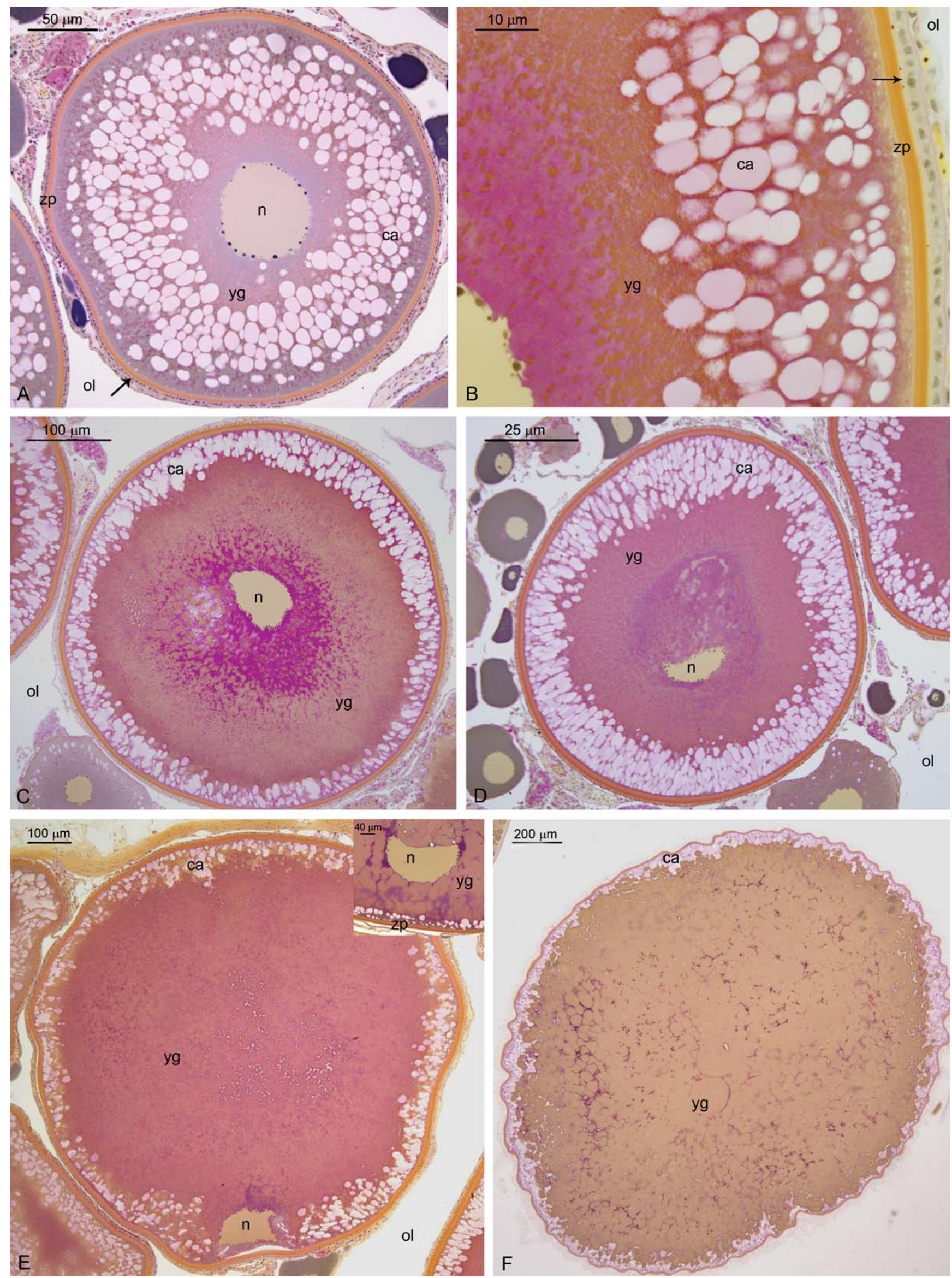
in the fish ovary (Grier, 2000, 2002; Grier \& Lo Nostro, 2000; Parenti \& Grier, 2004; Grier et al., 2005, 2007). The proliferation of oogonia and their entrance into meiosis gives rise to clusters of oocytes and epithelial cells, forming inpockets from the epithelium that protrude into the stroma. These clusters are the cell nests (Selman et al., 1993; Grier, 2000), but the "epithelial cells" are now called "prefollicle cells". The cell nests are attached to the germinal epithelium, both are separated from the stroma by a continuous basement membrane. Around late pachytene, the prefollicle cells begin to increasingly surround the oocytes that become individualized (Grier, 2000; Matova \& Cooley, 2001). Inside the nests, at the time of the meiotic arrest, the ovarian follicles begin to form. Ovarian follicles are composed of a diplotene oocyte that is surrounded by a layer of follicle cells; the follicle is encompassed by a basement membrane. Still inside the nests, the oocyte may enter primary growth designated by a basophilic ooplasm. Once the synthesis of the basement membrane is completed around the ovarian follicle, it is no longer part of the cell nest but remains connected to the germinal epithelium along a shared length of the basement membrane between them. The follicular complex is formed when the ovarian follicle is encompassed by cells derived from the stroma forming the thecal layers (Grier et al., 2009). As it can be appreciated in Gymnotu sylvius that the follicular complex remains connected to the germinal epithelium by a share basement membrane throughout its development. The development of the ovarian follicle and follicle complex is identical in both perciform (Grier, 2000; Grier et al., 2009) and in gymnotiforms; it is conserved between ostariophysian and perciform fish.

Within the follicle complex, the oocyte develops during primary growth and at the appropriate time and stimulus (see Patiño \& Sullivan, 2002; Lubzens et al., 2009 for review), enters in secondary growth. The primary growth stage also known as the previtellogenic stage (sensu Grier et al., 2009) involves the preparation of the oocyte for secondary growth during which vitellogenesis, and a huge increase in oocyte size, occurs. It is during primary growth that oocyte structures such as the cortical alveoli appear, the zona pellucida is formed and the basement membrane becomes thicker (see Selman et al., 1988; Selman \& Wallace, 1989; Patiño \& Sullivan, 2002; Grier et al., 2009 for review). The zona pellucida continues its formation during secondary growth.

\section{OOCYTE DEVELOPMENT}

Saltwater Perciform Fish Oocytes Freshwater Ostariophysan Fish Oocytes $\sqrt{ }$

\begin{tabular}{|c|c|c|c|}
\hline $\begin{array}{c}\text { ACTIVE MEIOSIS I } \\
\text { CHROMATIN NUCLEOLUS } \\
\text { STAGE (ON) }\end{array}$ & $\begin{array}{l}\text { PRIMARY GROWTH } \\
\text { STAGE (PG) } \\
\text { (LATE DIPLOTENE) }\end{array}$ & $\begin{array}{l}\text { SECONDARY } \\
\text { GROWTH STAGE (SG) } \\
\text { (LATE DIPLOTENE) }\end{array}$ & $\begin{array}{l}\text { ACTIVE MEIOSIS II } \\
\text { OOCYTE MATURATION } \\
\text { STAGE (OM) }\end{array}$ \\
\hline (CNI) & (PGon) & (SGe) & (OMegv) \\
\hline LEPTOTENE & ONE NUCLEOLUS & EARLY SG & ECCENTRIC GERMINAL VESICLE \\
\hline (CNz) & (PGmn) & (SGI) & \multirow{2}{*}{$\begin{array}{l}\text { oil globules coalesce } \\
\text { to form one } \\
\text { (OMgvm) }\end{array}$} \\
\hline ZYGOTENE & MULTIPLE NUCLEOLI & LATE SG & \\
\hline (CNp) & (PGpn) & (SGfg) & GERMINAL VESICLE MIGRATION \\
\hline PACHYTENE & PERINUCLEAR & FULL-GROWN OOCYTE & \multirow{2}{*}{$\begin{array}{l}\text { yolk globules } \\
\text { coalesce, yolk clears } \\
\text { (OMGgvb) }\end{array}$} \\
\hline (CNed) & (PGod) & & \\
\hline EARLY DIPLOTENE & OIL DROPLETS & & GERMINAL VESICLE BREAKDOWN \\
\hline NE beginning of chromosome condens & (PGca) & & \multirow{2}{*}{$\begin{array}{c}\text { (OMmr) } \\
\text { MEIOSIS RESUMES, ARRESTS } \\
\text { IN METAPHASE II: PREOVULATORY }\end{array}$} \\
\hline $\begin{array}{l}\text { NE homologous chromosomes } \\
\text { ring and condensing }\end{array}$ & CORTICAL ALVEOLAR & & \\
\hline $\begin{array}{l}\text { ENE chromosomes condensed, paired } \\
\text { IPLOTENE chromosomes disperse, lan } \\
\text { basophilia }\end{array}$ & (2) & & $\begin{array}{cc}\begin{array}{c}\text { Single oil } \\
\text { globule, yolk } \\
\text { clear }\end{array} & \begin{array}{c}\text { No oil } \\
\text { globule, yolk } \\
\text { not clear }\end{array}\end{array}$ \\
\hline
\end{tabular}

Fig. 7. Schema comparing oocyte development in a saltwater perciform, Sciaenops ocellatus and in a freshwater gymnotiform, Gymnotus sylvius. 
The zona pellucida is a multilayer, acellular structure that surrounds the eggs in which the outer layer is usually rich in polysaccharides, as the innermost is constituted by proteins, the choriogenins (see Patiño \& Sullivan, 2002; Modig et al., 2007 for review). The synthesis of the proteins that constitute the zona pellucida is attributed to the oocyte, to the liver or both of them depending of the species (see Modig et al., 2007 for review). Considering electron microscopy images of oocyte development in Gymnotus sylvius, the synthesis of the zona pellucida appears to involve both the oocyte and an external source that according the available data on the literature must be the liver (see Modig et al., 2007 for review).

The basement membrane is also an acellular structure that supports the follicle cells and surrounding them delineates the encompassed ovarian follicle. Despite the synthesis of basement membrane components that have been attributed (assigned) to the follicle cells themselves (Le Menn et al., 2007), until today there is no clear evidence that this supposition has been proven. Electron micrographs of oocyte development in Gymnotus sylvius could constitute the lacking evidence for this. As seen in Gymnotus sylvius, the basement membrane is a multilayered structure built layer by layer external to the follicle cells, not the thecal cells. The obvious conclusion is that the follicle cells are solely responsible for the formation of the multiple layers of basement membrane in Gymnotus sylvius, so far a unique phenomenon among teleosts.

Among the thecal layers in the follicular complex of Gymnotus sylvius, some cells are observed with steroidogenic characteristics very similar to the Leydig cells (Pudney, 1995, 1996, 1998). Female cells with steroidogenic features have been reported from the more basal to the more derived Teleostei taxa (McMillan, 2007), including the Ostariophysi (Quagio-Grassiotto \& Guimarães, 2003). These findings support the hypothesis that they should be a common component of the follicular complex of teleost fish.

At the end of the secondary growth stage, the oocyte is full-grown and ready to enter maturation. Maturation is induced by a hormonal stimulus (see Patiño \& Sullivan, 2002; Grier et al., 2009; Lubzens et al., 2009 for review) and prepares the oocyte for ovulation. Besides nuclear (germinal vesicle) migration, some other morphological events reported to occur during oocyte maturation and or preceding ovulation are the fusion of the lipid droplets and the pronounced hydrolysis and hydration of the yolk. The deposition of lipids is disseminated but not an exclusive characteristic of saltwater perciform species eggs as is the pronounced hydrolysis and hydration of the yolk during maturation, also observed in pelagic eggs (Patiño \& Sullivan, 2002; Cerdá et al., 2007; Le Menn et al., 2007; Grier et al., 2009). Gymnotus sylvius is a freshwater ostariophysian fish in which the oocyte does not possess lipid droplets. Several other species of ostariophysians also do not possess lipid droplets (Bazzoli \& Rizzo, 1990; Gomes et al., 2007; Martins et al., 2009). Also in Gymnotus sylvius, the hydrolysis and hydration of the yolk preceding ovulation is modest as expected for fish that produce benthophil eggs (LaFleur et al., 2005). The yolk globules have an irregular outline in full-grown, mature oocytes and recently ovulated eggs in Gymnotus sylvius. However, these yolk globules are still discrete, and do not become fluid as in pelagic eggs of Perciformes. The data from Gymnotus sylvius added of that available from oocyte development, maturation and ovulation of other species of Ostariophysi suggests that the absence of lipid droplets and the lack of pronounced hydrolysis and hydration of the yolk could be a common characteristic of the oocytes in this group of fish.

Considering the call of Grier et al. (2009) for updating and standardizing the concepts and terminology utilized in studies on folliculogenesis and on oocyte development in fish, herein the unifying terminology proposed by these authors was only slightly modified to be applied to describe both folliculogenesis and oocyte development in Gymnotus sylvius. Despite the fact that the staging schema for oocyte development of these authors was developed from studies of higher Teleostei, primarily a few marine species (Grier et al., 2009), it was easily adapted to Gymnotus sylvius, a freshwater, ostariophysian fish. The structural aspects of folliculogenesis and most of the cellular events appear to be constants throughout oocyte evolution in fish, and the origin of ovarian follicles is precisely identical between Gymnotus and Centropomus (Grier, 2000) and other fish species (Parenti \& Grier, 2004). However, the studies regarding Gymnotus sylvius, and other freshwater Ostariophysi (Bazzoli \& Rizzo, 1990; Gomes et al., 2007; Martins et al., 2009) have shown some significant differences in egg morphology from other studied fish. In an attempt to have a schema that could also be applied to the ostariophysians, a schema from Quagio-Grassiotto et al. (2009) is been presented (Fig. 7), comparing oocyte development in a saltwater perciform, Sciaenops ocellatus and Gymnotus sylvius, and showing the differences between them.

\section{Acknowledgements}

We would like to thank the Electron Microscopy Laboratory/IBB-UNESP for use of its facilities. This research was supported by the Brazilian Agencies: FAPESP (Fundação de Apoio à Pesquisa do Estado de São Paulo); CNPq (Conselho Nacional de Desenvolvimento Científico e Tecnológico); CAPES/PROEX (Coordenação de Aperfeiçoamento de Pessoal de Nível Superior).

\section{Literature Cited}

Alves-Gomes, J. A., G. Ortí, M. Haygood \& W. Heiligenberg. 1995. Phylogenetics analysis of the South American electric fishes (Order Gymnotiformes) and evolution of their system: a synthesis based on morphology, electrophysiology, and mitochondrial sequence data. Molecular Biology Evolution, 12: 298-318. 
Bazzoli, N. \& E. Rizzo. 1990. A comparative cytological and cytochemical study of oogenesis in ten Brazilian teleost fish species. European Archives of Biology, 101: 399-410.

Cerdà, J., M. Fabra \& D. Raldúa. 2007. Physiological and molecular basis of fish oocyte hydration. Pp. 349-396. In: Babin, P. J., J. Cerdà \& E. Lubzens (Eds.). The Fish Oocyte: From Basic Studies to Biotechnological Applications. Dordrecht, Springer, $508 \mathrm{p}$.

Gomes, B. V. C., R. S. Scarpelli, F. P. Arantes, Y. Sato, N. Bazzoli, \& E. Rizzo. 2007. Comparative oocyte morphology and early development in three species of trahiras from the São Francisco River basin, Brazil. Journal of Fish Biology, 70: $1412-1429$.

Grier, H. J. 2000. Ovarian germinal epithelium and folliculogenesis in the Common Snook, Centropomus undecimalis (Teleostei: Centropomidae). Journal of Morphology, 243: 265-281.

Grier, H. J. 2002. The germinal epithelium: its dual role in establishing male reproductive classes and understanding the basis for indeterminate egg production in female fishes. Pp. 537-552. In: Creswell, R. L. (Ed.). Proceedings of the fiftythird annual Gulf and Caribbean Fisheries Institute, November 2000. Fort Pierce, Mississippi/Alabama Sea Grant Consortium.

Grier, H. J. \& F. L. Lo Nostro. 2000. The germinal epithelium in fish gonads: the unifying concept. Pp. 233-236. In: Norberg, B., O. S. Kjesbu, G. L. Taranger, E. Andersson \& S. O. Stefansson (Eds.). Proceedings of the 6th International Symposium on the Reproductive Physiology of Fish. Norway, University of Bergen.

Grier, H. J \& L. P. Parenti. 2004. Evolution and phylogeny of gonad morphology in bony fishes. Society of Integrative and Comparative Biology, 44:333-348.

Grier, H. J., M. C. Uribe, L. R. Parenti \& G. Rosa-Cruz. 2005. Fecundity, the Germinal, and Folliculogenesis in Viviparous fishes. Pp. 191-216. In: Uribe, M. C. \& H. J. Grier (Eds.). Viviparous Fishes. Homestead, New Life Publication.

Grier, H. J., M. C. Uribe \& L. R. Parenti. 2007. Germinal epithelium, folliculogenesis, and postovulatory follicles in ovaries of rainbow trout, Oncorhynchus mykiss (Walbaum, 1792) (Teleostei, Protacanthopterygii, Salmoniformes). Journal of Morphology, 268:293-310.

Grier, J. H., M. C. Uribe \& R. Patiño. 2009. The ovary, folliculogenesis and oogenesis in teleosts. Pp. 25-84. In: Jamieson, B. J. M. (Ed.). Reproductive Biology and Phylogeny of Fishes (Agnathans and Bony Fishes) Phylogeny Reproductive System Viviparity Spermatozoa. Science Publishers, Enfield.

LaFleur, G. F., D. Raldúa, M. Fabra, O. Carnevali, N. Denslow, R. A. Wallace \& J. Cerdà. 2005. Derivation of major yolk proteins from parental vitellogenin, and alternative processing during oocyte maturation in Fundulus heteroclitus. Biology of Reproduction, 73: 815-824.

Le Menn, F., J. Cerdà \& P. J. Babin. 2007. Ultrastructural aspects of the ontogeny and differentiation of ray-finned fish ovarian follicles. Pp. 1-37. In: Babin, P. J., J. Cerdà \& E. Lubzens (Eds.). The Fish Oocyte: From Basic Studies to Biotechnological Applications. Dordrecht, Springer, 508p.

Lubzens, E., G. Young, J. Bobe \& J. Cerdà. 2009. Oogenesis in teleosts: How fish eggs are formed. General and Comparative Endocrinology. 165: 367-389.
Mago-Leccia, F. 1994. Electric Fishes of the Continental Waters of America. Venezuela, FUDECI, 229p.

Martins, Y. S., D. F. de Moura, G. B. Santos, E. Rizzo \& N. Bazzoli. 2009. Comparative folliculogenesis and spermatogenesis of four teleost fish from a reservoir in southeastern Brazil. Acta Zoologica (Stockholm), 91: 466-473.

Matova, N. \& L. Cooley. 2001. Comparative aspects of animal oogenesis. Development Biology, 231: 291-320.

McMillan, D. B. 2007. Fish Histology. Female Reproductive System. Springer, Dordrecht, 598p.

Modig, C., L. Westerlund \& P.-E. Olsson. 2007. Oocyte zona pellucida proteins. Pp. 113-140. In: Babin, P. J., J. Cerdà \& E. Lubzens (Eds.). The Fish Oocyte: From Basic Studies to Biotechnological Applications. Springer, Dordrecht, 508p.

Parenti, L. R. \& H. Grier. 2004. Evolution and phylogeny of gonad morphology in bony fishes. Integr Comparative Biology, 44 : 333-348.

Patiño, R. \& C. V. Sullivan. 2002. Ovarian follicle growth, maturation, and ovulation in teleost fish. Fish Physiology and Biochemistry, 26: 57-70.

Pearse, A. G. E. 1985. Histochemistry: theoretical and applied. Churchill Livingstone, London.

Pudney, J. 1995. Spermatogenesis in Nonmammalian Vertebrates. Microscopy Research Technology, 32: 459-497.

Pudney, J. 1996. Comparative Cytology of the Leydig Cell. Pp. 98142. In: Payne, A. H., M. P. Hardy \& L. D. Russel (Eds.). The Leydig Cell. Vienna, Cache River Press.

Pudney, J. 1998. Leydig and Sertoli Cells, Nonmmamalian. Pp. 1008-1020. In: Knobil, E., \& J. D. Neill (Eds.). Encyclopedia of Reproduction. Academic Press: San Diego.

Quagio-Grassiotto, I. \& A. C. D. Guimarães, 2003. Follicular epithelium, theca and egg envelop formation in Serrasalmus spilopleura (Teleostei, Characiformes, Characidae). Acta Zoolologica (Stockolm), 84: 121-129.

Quagio-Grassiotto, I., G. F. França, T. S. Mazzoni \& H. Grier, 2009. A new approach to oocyte development in Ostariophysi. Animal Biology of Reproduction, 6: 269.

Quintero-Hunter, I., H. Grier \& M. Muscato. 1991. Enhancement of histological detail using metanil yellow as counterstain in periodic acid/Schiff's hematoxylin staining of glycol methacrylate tissue sections. Biotechnic and Histochemmistry, 66: 169-172.

Selman, K., R. A. Wallace \& V. Barr. 1988. Oogenesis in Fundulus heteroclitus. V. The relationship of yolk vesicle and cortical alveoli. Journal of Experimental Zoology, 246: 42-56.

Selman, K. \& R. A. Wallace. 1989. Cellular aspects of oocyte growth in teleosts. Zoological Science, 6: 211-231.

Selman, K., R. A. Wallace, A. Sarka, \& X. Qi. 1993. Stages of oocyte development in the zebrafish, Brachydanio rerio. Journal of Morphology, 218: 203-224.

Wallace, R. A. \& K. Selman. 1981. Cellular and dynamic aspects of oocyte growth in teleosts. American Zoologist, 21: 325-343.

Wallace, R. A. \& K. Selman. 1990. Ultrastructural aspects of oogenesis and oocyte growth in fish and amphibians. Journal of Electron Microscopy and Technique, 16: 171-201.

Accepted August 31, 2010

Published December 16, 2010 